\title{
ESTETIKA WANGSALAN DALAM LAGU SINDHENAN KARAWITAN JAWA
}

\author{
Sukesi Rahayu \\ Jurusan Pedalangan Fakultas Seni Pertunjukan \\ Institut Seni Indonesia Surakarta \\ JI. Ki Hajar Dewantara 19 Kentingan, Jebres, Surakarta 57126
}

\begin{abstract}
ABSTRAK
Sindhenan merupakan salah satu aspek penting dalam pergelaran Karawitan Jawa baik dalam pertunjukan mandiri maupun fungsi karawitan sebagai salah satu pendukung pertunjukan yang memiliki unsur-unsur estetis maupun etis. Unsur-unsur estetis berkaitan dengan bentuk susunan frasa serta diksi yang digunakan dalam teks sindhenan, antara lain yang terdapat dalam wangsalan. Wangsalan merupakan salah satu teks sindhenan yang memiliki kandungan nilai yang dihayati dan diyakini sebagai pandangan hidup masyarakat jawa, nilainilai tersebut selanjutnya disebut sebagai nilai etis yang terbingkai dalam budaya jawa. Penelitian ini merupakan penelitian yang mengkaji makna yang terkandung dalam wangsalan sindhenan yang dikaji dengan perspekstif estetika bunyi dan persajakan. Metode yang digunakan dalam penelitian ini merupakan model penelitian kualitatif dimana data yang disajikan merupaka data yang diperoleh secara langsung dari lapangan, dengan sudut pandang penulis sebagai pelaku. Hasil dari penelitian ini mengungkap makna yang terkandung dalam wangsalan yang disampaikan oleh seorang sindhen hubunganya dengan ideologi serta cara pandang orang jawa dalam memaknai kehidupan.
\end{abstract}

Kata kunci: Sindhen, Wangsalan, Estetika Bunyi.

\begin{abstract}
Sindhenan is an important aspect in the performance of Javanese Karawitan both in independent performances and karawitan functions as one of the supporting aspects of the performance that has aesthetic and ethical elements. Aesthetic elements are related to the form of the phrase structure and the diction used in the sindhenan text, including those in the wangsalan. Wangsalan is one of the sindhenan texts which has values that are appreciated and believed to be a Javanese view of life. These values are then referred to as ethical values framed in Javanese culture. This research studies the meaning contained in the sindhenan wangsalan which is studied with aesthetic perspectives of sound and poetry. The method used in this study is a qualitative research model where the data presented is data obtained directly from the field, with the author's perspective as the actor. The results of this study reveal the meaning contained in wangsalan conveyed by a sindhen in relation to the Javanese view and ideology in interpreting life.
\end{abstract}

Keywords: Sindhen, Wangsalan, Sound Aesthetics.

\section{A. Pengantar}

Pesindhen berasal dari kata Pasindyan, yang secara ethimologis berarti seseorang yang melagukan nyanyian berisi sindiran-sindiran kehidupan (zoetmoelder, 1995: 1094). Pesindhen juga lazim disebut sebagai juru kawi, yakni orang yang memiliki kemampuan berbahasa kawi, dimana bahasa kawi adalah bahasa yang digunakan di dalam serat-serat dan manuskrip kuno. Manuskrip atau serat-serat lama yang ditembangkan oleh sindhen, tentunya merupakan serat-serat yang berisi banyak hal, diantara lain adalah nilai-nilai kehidupan yang saat itu dianggap relevan. Belum banyaknya media informasi yang berkembang, membuat posisi juru kawi saat itu sangatlah dibutuhkan, terutama sebagai sarana pendidikan bagi masyarakat kecil, sedangkan nyanyian atau lagu yang ditembangkan seorang sindhen ini lazim disebut sebagai sindhenan.

Kehadiran seorang sindhen dalam panggung kesenian setidaknya dapat kita perkirakan telah ada sejak 908 Masehi, seperti yang disebutkan dalam prasasti Wukujana bahwa pada saat itu telah ada sebuah pertunjukan drama yang dibawakan oleh beberapa orang, ada yang mendalang, ada yang melawak, serta diiringi oleh seseorang yang 
menyanyikan tembang, dengan lakon Bhima Khumara (Haryana, dalam Suyanto 2009:2). Artinya bahwa posisi seorang pelantun tembang (Sindhen) sejak dulu telah memiliki tempat tersendiri dalam sebuah pertunjukan yang bersifat ritus dikarenakan selain memiliki estetika bunyi yang dapat dinikmati, tembang-tembang tradisi juga memiliki muatanmuatan yang berisi nilai-nilai etis yang berisi nilainilai kehidupan didukung dengan pemilihan kata yang semakin menguatkan makna (Sudarko, 2013: 59).

Dewasa ini, fungsi sinden tidak hanya sebagai penyampai nilai-nilai kehidupan yang universal. Selain juga sebagai penghias lagu, sindhen juga diposisikan sebagai seorang penghibur yang menjadi daya tarik pementasan. Kasus ini dapat ditemukan pada beberapa dekade terakhir. Dalam panggung wayang kulit misalnya, pada tahun 60 -an, posisi duduk sindhen berada di belakang dalang sejajar dengan pengendhang, dengan dandanan yang sederhana bahkan tak jarang tanpa menggunakan make-up, artinya pada waktu itu satu-satunya icon yang ditampilkan dari seorang pesindhen adalah kemampuan tarik suara, serta menguasai berbagai bentuk tembang dalam bingkai karawitan pakeliran.

Dekade 70-n, ketika nama Nartosabdo mulai naik daun, dalam sebuah pergelaran wayang, posisi tempat duduk sindhen mulai digeser menjadi disamping sang dalang, hal ini disinyalir kedudukan sindhen sudah tidak lagi menjadi penghias lagu semata, namun juga menjadi sebuah icon pertunjukan yang dijual sebagai bagian dari kemasan atau perabot fisik pertunjukan wayang yang dianggap memiliki daya tarik tersendiri (Manteb Soedarsono, wawancara: 21 september 2017).

Bergesernya posisi sindhen sebagai objek tontonan, menjadikan sindhen kadang hanya dipandang sebagai objek eksploitasi visual saja, hal ini juga berdampak terhadap cara pandang masyarakat awam kepada pesindhen itu sendiri yang kadang dipandang dalam segi negative saja, hal-hal negative yang dimaksud adalah posisi sindhen selalu dikaitkan dengan rendahnya moralitas yang disebabkan oleh kehadiran sindhen dimaknai sebagai semata-mata penghibur yang datang hanya untuk menuntaskan hasrat penonton yang haus hiburan, maka dari itu menurut penulis diperlukan adanya kajian secara teoritis mengenai unsur-unsur sindhenan terutama mengenai makna teks yang disampaikan hubunganya dengan nilai estetika dan etika yang terkandung dalam wangsalan sindhenan pada karawitan Jawa.

\section{B. Sindhenan dalam Karawitan Jawa}

Sindhenan merupakan lagu atau nyanyian yang dihasilkan seorang pesindhen yang dilagukan secara tunggal dan disajikan bersama-sama dengan beberapa atau seluruh ricikan gamelan yang mempresentasikan sebuah bentuk gendhing ( Sukesi, 2017:41). Sindhenan berdiri sendiri sebagai bentuk sajian vokal dalam karawitan jawa, disamping gerongan, macapat, dan bawa. Selain sebagai penghias lagu, sindhenan juga memiliki peranan penting dalam memberi ide musikal ricikan-ricikan garap seperti rebab, kendhang, gender barung, bonang barung. Serta membangun rasa pada sebuah gendhing.

Sebagai sebuah sajian vokal, sindhenan memiliki dua unsur yang saling terkait dalam penyajianya yakni lagu dan cakepan. Dua unsur ini sama sekali tidak dapat dipisahkan dalam sajian vokal sindhenan, lagu merujuk pada jalinan nada yang dibentuk dalam sajian sebuah gendhing, yang berhubungan dengan interprestasi pesindhen terhadap sebuah gendhing. Interprestasi pesindhen terhadap sebuah gendhing adalah hal yang tidak mudah dilakukan, hal ini ditentukan oleh beberapa faktor antara lain penguasan cengkok, dan kekuatan dalam menafsir sindhenan itu sendiri. Maka dari itu banyak hasil sindhenan yang berbeda meskipun dalam penyajian gendhing yang sama (Suraji, 2005: 2).

Sedangkan cakepan atau syair merujuk pada teks-teks yang digunakan dalam melagukan tekhnik sindhenan, teks-teks ini biasanya menggunakan karya sastra lama seperti serat wedhatama, wulangreh, serat tripama, serat rama dan masih banyak lagi, bahkan dalam sindhenan Jawatimuran, teks-teks tersebut berkembang tidak hanya berpedoman pada serat-serat lama namun juga dibuat secara spontan diatas panggung, kasus ini biasanya banyak didapati dalam penggunaan teks parikan. Khusus dalam unsur teks ini, akan diuraikan lagi beberapa jenis teks dalam sajian sindhenan pada karawitan jawa, teks tersebut antara lain:

\section{Wangsalan}

Wangsalan merupakan satu kalimat yang terdiri dari dua frase atau lebih, dan didalamnya terdapat teka-teki yang jawabanya berhubungan dengan kalimat tersebut. Cara memecahkan teka-teki pada teks wangsalan adalah dengan cara menghubungkan kata yang terdapat pada kalimat tersebut (Waridi, 2002: 127-128)

Padmosoekotjo mengklasifikasi wangsalan menjadi empat jenis, yaitu: (1) wangsalan lamba, (2) 


\section{GE[AR sumal Sori Bublya}

wangsalan rangkep (camboran), (3) wangsalan memet, dan (4) wangsalan padinan (1960:6). Wangsalan lamba adalah jenis wangsalan yang inti jawabannya hanya satu, misalnya:

- Pindhang lulang (= krècèk) kacèk apa aku karo kowé.

- Janur gunung (= arèn) kadingarèn kowé teka.

- Jenang gula (= glali) aja lali karo aku iki.

- Balung klapa (= bathok) éthok-éthok ora ngerti.

Wangsalan rangkep (camboran) adalah jenis wangsalan yang isi jawabannya lebih dari satu. Wangsalan ini terdiri dari dua frasa, frasa pertama merupakan teka-teki, sedangkan frasa kedua merupakan jawabannya. Misalnya:

- Jenang séla (= apu) wader kali sesondhèran (= sepat), apuranta yèn wonten lepat kawula.

- Jarwa surya (= srengéngé) surya lumebèng ancala (= surup), srenging karsa mung nedya nyumurupana.

- Riris harda (= deres) hardané wong lumaksana (= mlayu), dresing karsa memayu hayuning praja.

- Déwa tirta (= Baruna) lampahé amungu néndra (= subuh), pra taruna mati alabuh nagara.

Wangsalan memet adalah jenis wangsalan yang dalam mencari jawabannya dengan menggunakan perbendaharaan kata sampai dua kali. Misalnya:

- Uler kambang (= lintah) yèn trima alon-alonan (= satitahé, sakepénaké)

- Ngebun-ebun énjang (= awun) njejawah sonten (= tarabi/rarabi).

Wangsalan padinan adalah jenis wangsalan yang tidak memerlukan jawaban, karena dianggap orang lain yang diajak berbicara sudah mengetahui jawabannya. Misalnya:

- Wong kaé sajatiné krungu kandhaku, ning njangan gori (= gudheg = mbudheg).

- Ésuk-ésuk kok wis nggodhong garing (= klaras = nglaras).

- Aja njenang gula karo aku (= glali = lali).

- $m$ Bok aja ngrokok cendhak (= tegesan = neges neges).

Selain terdapat pada sajian sindhenan Jawa Tengah, penggunaan wangsalan saat ini juga lazim digunakan dalam sajian gendhing Jawa Timuran, Hal itu terbukti bahwa teks yang digunakan juga sama dengan teks wangsalan sindhènan Jawa Tengah, antara lain:
- Carang wreksa, wreksa wilis tanpa patra; nora gampang, wong urip nèng ngalam ndonya.

- Petis manis, sariné kaca brenggala; aja ngucap, yèn durung weruh ing rasa.

- Ngréka puspa, puspa kang nedheng wèh ganda; gubah basa, mingkar-mingkur ing angkara.

- Sukèng ndriya, ndriya sengsem rèh ngaksama; murih rena, nenangi manah martana.

- Ari Séna, Séna gelung minangkara; ngèsthi arga, luhur darajating bangsa.

- Kresna putra, putra Risang Dananjaya; sinambada, sih tresna sahabimanyu.

\section{Parikan}

Parikan juga dapat disebut pantun jawa, adalah sebuah kalimat yang terdiri dari dua frasa, yang pada akhir frasa pertama dan frasa kedua mempunyai kesamaan bunyi vokal (Jawa: guru lagu atau guru swara). Frasa pertama berisi teks pertanyaan, sedangkan frasa kedua berisi jawaban. Setiap frasa tidak dibatasi oleh jumlah suku kata; ada yang 4 suku kata, 5 suku kata, 6 suku kata, 8 suku kata, bahkan 10 sampai 12 suku kata. Berikut ini beberapa contoh parikan dengan variasi jumlah suku kata pada setiap frasa.

(1) Parikan yang dalam setiap frasa terdiri dari 4-4 suku kata $X 2$ :

"Pitik blorok, ngendhog siji, jaré kapok, malah ndadi."

(2) Parikan yang dalam setiap frasa terdiri dari 4-6 suku kata $X 2$ :

"Numpak dhèlman, lunga nyang Betawi, nèk berjuang, kudu wani mati."

(3) Parikan yang dalam setiap frasa terdiri dari $8-8$ suku kata $X 2$ :

"Jangan krokot jangan ulur, terik témpé pinggir sumur, tresna abot manjing dulur, bisa awèt panjang umur."

(4) Parikan bebas, adalah jenis parikan yang jumlah suku kata dalam setiap frasa tidak menentu:

"Aja nggulani lopis sak iris, lopis sak iris campuren klapa

Aja mbélani penjajah imperalis, bélanana nasibé nusa lan bangsa."

Menurut Soebagyo (1992:vii-viii), parikan terbagi dalam dua bagian yang funda-mental, yang disebut sampiran dan isi. Sampiran adalah bagian pertama yang merupakan wadah, sedangkan isi adalah bagian kedua yang merupakan pelengkap, pasangan, atau jodoh bagi wadah yang sudah 
dipersiapkan. Ditinjau dari bentuknya, sampiran berisi bunyi yang merupakan tantangan, sedangkan isi merupakan jawaban atas tantangan itu. Kedua unsur ini harus serasi dan saling melengkapi. Selanjutnya dijelaskan bahwa parikan yang ideal mempunyai kriteria sebagai berikut.

1. Terdiri atas dua baris (disebut parikan tunggal) atau empat baris (disebut parikan ganda); masingmasing baris disebut gatra;

2. Masing-masing gatra terdiri atas dua potongan (disebut pedhotan);

3. Masing-masing pedhotan terdiri atas empat suku kata (disebut wanda);

4. Pada parikan dua gatra, gatra pertama adalah sampiran dan gatra kedua adalah isi;

5. Pada parikan empat gatra, dua gatra pertama adalah sampiran dan dua gatra kedua adalah isi;

6. Sajak parikan berupa sajak silang: $a-b$ untuk parikan tunggal, a-b-a-b untuk parikan ganda.

Contoh parikan tunggal:

(1) Abang-abang ora legi, Klambi abang manas ati.

(Merah-merah tidak manis,

Baju merah bikin panas.)

(2) Brambang diiris-iris,

Mata abang mentas nangis.

(Bawang diiris-iris,

Mata merah baru saja menangis.)

Contoh parikan ganda:

(1) Jangan krokot jangané alur, terik dhéwé pinggir sumur; Trisna abot manjing sedulur, Kenèka awèt sak-umur-umur.

(Sayur kerokot sayur aluran, dimasak terik di pinggir sumur;

Cinta yang berat menjadi saudara, Semoga tahan sepanjang umur.)

(2) Taksi nggak kurang taksi, nyegat oplèt kliru praoto; Aksi nggak kurang aksi, mbukak dhompèt isiné mbako.

(Taksi tidak kurang taksi, mencegat oplet keliru prahoto;

Aksi tidak kurang aksi, membuka dompet isinya tembakau

\section{Senggakan}

Kata senggakan memiliki kata dasar senggak yang berarti "nyuwara giyak aramé mbarengi (nyambungi) uniné gamelan" (bersuara ramai kegirangan menyertai suara gamelan). Senggakan berarti "tetembangan sing dienggo senggak" yaitu vokal tunggal atau bersama-sama dalam suasana riuh yang menyertai suara gamelan (Prawiroatmojo, 1985:II:186). Dengan demikian senggakan dapat diartikan:

vokal bersama atau tunggal dengan menggunakan cakepan parikan dan/atau serangkaian kata-kata (terkadang tanpa makna) yang berfungsi untuk mendukung terwujudnya suasana ramai dalam sajian suatu gending (Suraji, 2005:48).

Senggakan pada umumnya dilakukan oleh sejumlah pengrawit atau wiraswara, bahkan kadangkadang juga oleh pesindhèn tetapi bukan vokal tunggal. Kedudukan senggakan dalam gending adalah untuk melengkapi teks atau cakepan pokok. Isi teks senggakan kadang-kadang tidak berkaitan dengan teks pokok. Namun demikian adakalanya senggakan berfungsi memberi komentar atau jawaban terhadap teks pokok.

\section{Abon-abon}

Abon-abon adalah cakepan sindhènan yang berfungsi sebagai pelengkap atau selingan teks pokok. Teks isèn-isèn tidak mempunyai hubungan kalimat dengan teks pokok, sehingga hanya berkedudukan sebagai pemanis sindhènan:

- Rama-rama ramané dhéwé

Man éman-éman

- La léla-léla

Ya ndhuk

Ya mas.

Mengingat keberadaan teks isèn-isèn ini difungsikan sebagai pelengkap, maka dalam praktiknya tidak harus disajikan, tidak pokok, hanya sebagai penghias atau pemanis. Pada bentuk gending tertentu dalam satu kalimat lagu kenong atau kalimat lagu gong kadang-kadang memiliki kalimat lagu yang panjang, sehingga untuk menambah ke-kosongan pada cakepan sindhènan diperlukan adanya isèn-isèn. 


\section{GEEAR Jumal Scri Bublya}

\section{Estetika Wangsalan Sindhenan}

Pesindhen sebagai juru tembang, atau seorang pashindyan seperti yang disebutkan didepan merupakan seorang yang melagukan teks yang berisi sindiran-sindiran kehidupan, sindiran yang dimaksud merupakan ajaran mengenai nilai moralitas yang terdapat pada setiap sendi kehidupan, artinya posisi sindhen bukan merupakan penghias lagu atau penghias pementasan semata terlebih sindhen merupakan seorang penyampai nilai-nilai yang brkaitan dengan kehidupan secara hakiki.

Untuk mengupas secara rinci teks-teks wangsalan dalam perspektif estetika tentunya perlu juga mengkaji pendekatan-pendekatan estetika bunyi dan persajakan yang digunakan untuk mengupas nilainilai yang terkandung. Wangsalan sidhenan sebagai salah satu bentuk kesusastraan jawa memiliki keindahan tersendiri hal ini dianalisis dari kata-kata yang disajikan dan juga makna yang terkandung dalam susunan kata tersebut, sebagaimana keindahan merupakan sesuatu yang memiliki unsur baik dan benar, unsur baik merujuk pada susunan wujud dari kata-kata yang disajikan, sedangkan benar merujuk pada nilai-nilai yang terdapat pada kata tersebut (Katsoff dalam Margono, 2004: 336). Wangsalan sebagai sebuah karya sastra memiliki susunan frasa yang estetik, untuk lebih jelasnya dapat dilihat melalui contoh sebagai berikut:

Garwa Nata, (prameswari): Istri Raja, Nata ing nagri Cempala, (waspada): Raja di Negara Cempala (Drupada)

Sari ratri, : Siang malam

Kudu Eling lan Waspada : Harus waspada dan berhati-hati

Penggalan wangsalan diatas menunjukan sebuah susunan frasa yang memiliki rima yang indah, rima tersebut terlihat pada pengulangan dua kata yang saling bersambungan, (Garwa Nata, Nata ing nagri Cempala) pengulangan kata Nata dalam wangsalan tersebut, memberikan kesan irama yang merdu, tertata dan kesan estetik pada pendengaran serta perasaan oleh sebab itu efek bunyi yang ditimbulkan menjadi semakin indah (Widiastuti, 2009: 11).

Selain pada jalinan rima, kesan estetik juga terdapat pada nilai-nilai yang terkandung di dalam wangsalan tersebut, wangsalan diatas memberikan sebuah pitutur (Nasehat) jawa yang mengajak setiap orang yang mendengarkan agar berhati-hati setiap waktu. (Sari ratri, kudu eling lan waspada). Kata sari dalam konteks ini bukan merupakan sari dalam artian inti ataupun pokok dari sesuatu, namun kata sari yang dimaksud merupakan bentuk pengucapan kata Sahari yang berarti satu hari, yang menjadi luluh karena tuntutan guru wilangan (jumlah kata dalam susunan puisi jawa). Contoh lain kesan estetik yang ditimbulkan pada wangsalan sindhenan terletak pada bentuk wangsalan sebagai berikut ini:

Witing klapa, $\quad$ : Pohon Klapa (Glugu; jw) Kalapa kang maksih mudha: Kelapa yang masih muda (Cengkir: jw)

Salugune, : Selayaknya

Mung mardi pikir raharja : Hanya mencari ketentraman jiwa

Dalam teks tersebut, pengulangan kata Klapa memperkuat frasa yang terbentuk dan memberikan kesan keindahan pada puisi tersebut, selain itu kesan estetik juga terbentuk atas sajak yang membentuk keselarasan bunyi yakni penggunaan konsonan (a) yang kuat: Klapa, Mudha, dan Raharja.

\section{Relevansi Nilai Wangsalan Sindhenan Krawitan Jawa Dalam Kehidupan Masyarakat Jawa.}

Wangsalan sindhenan sebagai salah satu bagian dari kebudayaan memiliki posisi yang khusus dalam kehidupan masyarakat jawa, hal ini dapat terlihat dari sebagian besar teks-teks sindhenan memuat nilai-nilai kehidupan yang sesuai dengan budaya jawa, nilai-nilai tersebut dihayati dan dijadikan cara pandang terhadap kehidupan bagi masyarakat dengan latar belakang kebudayaan jawa.

Nilai-nilai yang terkandung tersebut diantaranya adalah cara pandang hidup orang jawa terhadap Tuhan sebagai pencipta awal dan akhir kehidupan, ajaran-ajaran Ketuhanan semacam ini lazim disebut dengan konsep sangkan paraning dumadi, yakni sebuah keyakinan bahwa kehidupan manusia tidak bisa lepas dari Tuhan, hidup dari Tuhan dan akan kembali kepada Tuhan (Amir, 1991: 69). Wangsalan sindhen sebagai salah satu bentuk puisi jawa yang memuat pandangan hidup orang jawa, juga syarat akan ajaran-ajaran Ketuhanan, pengembangan dari ajaran tersebut selanjutnya berbentuk ajaran moral dan budi pekerti, nilai-nilai tersebut diantaranya tertuang dalam syair wangsalan sebagai berikut:

Kawis pita, (Maja): Buah kawis yang berwarna Kuning 
Kang lata kentiring toya (Larahan) : Daun-daun kering yang hanyut di sungai (Larahan: Jw)

Aja uwas, : Jangan Khawatir

Den sumarah mring hyang sukma : Pasrahlah kepada Tuhan.

Kawis pita merupakan ungkapan Jawa yang merujuk pada buah kawis yang berwarna kuning (Maja) maka dari itu jawaban atas susunan kata Kawis pita adalah (Aja), sedangkan kata lata kentiring toya merujuk pada arti larahan atau sampah daun kering, sehingga jawaban atas pertanyaan tersebut terletak pada kata sumarah, yang berarti pasrah. Teks wangsalan tersebut mengajak pendengar untuk menyingkirkan keraguan dalam kehidupanya dan berserah diri kepada Tuhan. Jelas tersirat pada syair tersebut bahwasanya masyarakat jawa menempatkan Tuhan diatas segala-galanya, sebagai tempat berserah diri dan menghilangkan segala kekhawatiran. Syair lain yang memuat nilai-nilai hubungan manusia dengan Tuhan juga terdapat pada syair lain, sebagai berikut:

We-ning angga : Air yang keluar dari badan

Peksi jamang ngucap Janma : Burung bermahkota yang bisa berbicara (Beo, Menco: $J W)$

Dipun enget, : Selalulah ingat

Lamun ketaman ing coba : Jika menerima cobaan.

Wasteng sela, : Nama lain dari sela (Batu, Watu:jw)

Sela kembang jro samodra : Batu berbentuk bunga dalam lautan (Karang)

Mituruta : Turutilah,

Marang wulang kang utama : Kepada ajaran utama

Selain nilai-nilai Ketuhanan yang tercakup dalam wangsalan sindhenan, nilai lain yang banyak terdapat dalam wangsalan sindhenan adalah nilai-nilai cinta kasih, nilai cinta kasih yang dimaksud adalah hubungan asmara antara pria dan wanita, Contoh wangsalan tersebut adalah:

$\begin{array}{ll}\text { Puspa kresna } & : \begin{array}{l}\text { Bunga yang berwarna hitam } \\ \text { (Telengan: jw) }\end{array} \\ \text { Sapu Bale Winantara: } & \begin{array}{l}\text { Pembersih tempat sementara } \\ \text { (Kelut: jw) }\end{array} \\ \text { Kalenglengan, } & : \begin{array}{l}\text { merasa bingung, } \\ \text { Kaluting lara asmara }\end{array} \\ \text { Kawi Nedha } & \text { Bingungnya dilanda cinta } \\ & \text { Bahasa kawi dari Meminta } \\ & \text { (Nyuwun; kw) }\end{array}$

Taksaka kang mawa pada : Ular yang berkaki (Buaya,

$\begin{array}{ll} & \text { Baya;jw) } \\ \text { Sun sesuwun } & \text { : saya berharap } \\ \text { Tumiliya karon Jiwa } & \text { : Segera dapat berdua }\end{array}$

Selanjutnya adalah nilai-nilai kenegaraan, nilai kenegaraan yang dimaksut adalah nilai-nilai yang berhubungan antara manusia sebagai rakyat (Kawula:jw) dan Raja atau pemimpin yang menjalankan jalannya pemerintahan. Nilai ini memposisikan orang jawa sebagai masyarakat yang tulus mengabdi dan memiliki dedikasi tinggi kepada negara atau kerajaan tempatnya mengabdi hidup dan mengabdi, selain itu nilai-nilai kenegaraan tersebut diantaranya juga berbicara mengenai sebuah identitas yang dijunjung tinggi dalam suatu negara, seperti Pancasila. Nilai-nilai tersebut terdapat pada syair wangsalan sebagai berikut:

$\begin{aligned} \text { Kawi lima } & \text { : } \\ & \text { Bahasa kawi dari bilangan } \\ & \text { lima (Panca: kw) }\end{aligned}$

Putra priya dahyang drona : Anak laki-laki Drona (Aswatama)

Pancasila : Pancasila

Dasaring nagri utama : Dasar dari sebuah negara yang baik.

Kukus Harga $\quad$ : Asap yang terdapat di Gunung (Ampak-ampak: jw)

Harga Wetan Surakarta : Gunung di Timur Surakarta (Lawu)

Kinapakna : Mau apa lagi,

Kawula mung nedya harja: Hamba hanya ingin sesuatu yang baik.

\section{E. Kesimpulan}

Sindhen sebagai seorang pasindhiyan atau seseorang yang melagukan syair yang berisi ajaranajaran kehidupan, memiliki tanggung jawab yang hampir sama dengan seorang dalang. Yakni menyampaikan nilai-nilai kehidupan yang hakiki. Karena pada kenyataanya syair-syair sindhenan yang salah satunya adalah wangsalan memiliki muatanmuatan etis maupun estetis. Muatan-muatan estetis terdapat pada pola penyusunan kalimat yang memiliki pola susunan rima yang indah dengan mempertimbangkan aspek pengulangan suara yang tidak membosankan, sehingga membentuk pola kalimat puitis. Sedangkan muatan-muatan etis terdapat pada syair yang diucapkan yang memuat 


\section{GE[AR Jumal Sori Bublya}

banyak nilai kehidupan, seperti nilai Ketuhanan, Nilai Cinta kasih dan Nilai pengabdian dan kenegaraan.

Nilai-nilai tersebut merupakan contoh kecil dari sekian banyak nilai yang terdapat pada wangsalan sindhenan, dengan kata lain wangsalan sindhenan bagi masyarakat jawa bukan saja dipandang sebagai pemanis lagu dalam susunan musikal karawitan jawa tetapi juga merupakan ideologi budaya yang menjadi pandangan hidup orang jawa dalam memaknai kehidupan.

\section{KEPUSTAKAAN}

Padmosoekotjo, S. 1960. Ngèngrèngan Kasusastran Djawa II. Jogjakarta: Hien Hoo Sing.

Perlman, Marc. 1993. "Unplayed Melodies: Music Theory in Postcolonial Java." Disertasi. Wesleyan: Wesleyan University.

Prawiroatmojo, S. 1985. Bausastra Jawa-Indonesia. Jilid I-II. Jakarta: Gunung Agung.

Proyek Penelitian dan Pencatatan Kebudayaan Daerah. 1976. Ensiklopedi Seni Musik dan Seni Tari Daerah Jawa Timur. Surabaya: Proyek Penelitian dan Pencatatan Kebudayaan Daerah, Departemen Pendidikan dan Kebudayaan.

Rahayu Supanggah. 1983. "Pokok-pokok Pikiran tentang Garap," makalah disajikan dalam diskusi mahasiswa dan dosen ASKI Surakarta.

1984. "Pengetahuan Karawitan," makalah Pengabdian pada Masyarakat (ASKI Surakarta).

1985. "Introduction aux styles d'interpretation dans la musique Javanais." Thèse de doctorat (musique), Université de Paris.

1990. "Balungan," dalam Seni Pertunjukan Indonesia, Jurnal Masyarakat Musikologi Indonesia Vol. I, No. 1:115-136.

1994. "Gatra, Inti dari Konsep Gendhing Tradisi Jawa," dalam Wiled, Jurnal Seni STSI Surakarta Th. I (1994):13-26. Surakarta: Sekolah Tinggi Seni Indonesia.
1996. "Seni Tradisi, Bagaimana la Berbicara," makalah Penataran Tenaga Peneliti Madia Dosen STSI Surakarta, pada tanggal 29 Juni 1996.

2002. Bothèkan Karawitan I. Jakarta: Ford Foundation dan Masyarakat Seni Pertunjuk-an Indonesia.

Slamet Suparno, T. 1984/1985. "Sindhènan Andhegan Nyi Bei Mardusari.” Laporan Penelitian ASKI Surakarta.

Soebagyo. 1992. Parikan Jawa Puisi Abadi. Jakarta: PT. Aksara Garda Pustakatama.

Soenarto, R.P. 1980. Tuntunan Belajar Dasar-dasar Tabuhan Karawitan Jawa Timuran. Surabaya: Sekolah Menengah Karawitan Indonesia.

Sri Hastanto. 1985. "The Concept of Pathet in Central Javanese Gamelan Music." Disertasi doktoral pada Durham University.

Sri Suyamti, V.M. 1985. "Garap Sindhènan Gendhinggendhing Surabaya di Dalam Laras Sléndro: Suatu Studi Kasus Gaya Remu di RRI Surabaya, Desa Embong Kaliasin, Kecamatan Genteng, Kodya Surabaya." Skripsi S-1. Surabaya: Sekolah Tinggi Kesenian Wilwatikta.

Sri Toporini. 1980. "Vokal Jineman Nyi Soemarmi." Skripsi Sarjana Muda ASKI Surakarta.

Sudarko. 2013. "Ragam Sulukan Wayang kulit Purwa Gaya Yogyakarta: Studi Kasus Timbul Hadiprayitno, Hadi Sugito, dan Suparman" dalam Resital Jurnal Seni Pertunjukan. Vol. 14 No. 1. Juni 2013: 56-70.

Sugeng Nugroho. 2003. "Studi tentang Pertunjukan Wayang Kulit Enthus Susmono." Tesis S2 Program Studi Pengkajian Seni, Program Pascasarjana Sekolah Tinggi Seni Indonesia (STSI) Surakarta.

2007. "Konsep-konsep Artistik dan Estetik Seni Pedalangan Jawa," dalam Dewaruci Vol. 4 No. 3, Desember 2007 (hal. 319-338). Surakarta: Program Pendidikan Pascasarjana Institut Seni Indonesia. 
Sukesi Rahayu, Garap Sindhenan Jawa Timur Surabayan, Surakarta: ISI Press, 2017

Sumarsam. 1976. "Inner Melody in Javanese Music." M.A. (music). Middletown, Connecticut: Wesleyan University.

2003. Gamelan: Interaksi Budaya dan Perkembangan Musikal di Jawa. Yogyakarta: Pustaka Pelajar.

Suraji. 2005. "Sindhenan Gaya Surakarta." Tesis S2 Program Studi Pengkajian Seni, Program Pascasarjana Sekolah Tinggi Seni Indonesia (STSI) Surakarta.

Suwarno. 1985. "Garap Sindhènan Gendhing Jawa Timur Gaya Mojokerto dalam Laras Sléndro: Suatu Studi Eksplore Toris Sulyani dan Suti'ah di Desa Randu Bangau, Kecamatan Mojosari, Kabupaten Mojokerto." Skripsi S1. Surabaya: Sekolah Tinggi Kesenian Wilwatikta.

Tim Penyusun Kamus Pusat Pembinaan dan Pengembangan Bahasa. 1989. Kamus Besar Bahasa Indonesia. Jakarta: Balai Pustaka.
Soenarto Timoer. 1998. Serat Wewaton Padhalangan Jawi Wetanan. Jilid I. Jakarta: Balai Pustaka.

Waridi. 2000. "Garap dalam Karawitan Tradisi: Konsep dan Realitas Praktik," makalah dipresentasikan dalam rangka Seminar Karawitan Program Studi S-1 Seni Karawitan, Program DUE-Like STSI Surakarta.

2001. Martapangrawit, Empu Karawitan Gaya Surakarta. Tesis S-2 Program Studi Pengkajian Seni Pertunjukan Uni-versitas Gadjah Mada Yogyakarta. Yogyakarta: Mahavira.

2002. "Jineman Uler Kambang: Tinjauan dari Berbagai Segi," dalam Dewa Ruci, Jurnal Pengkajian dan Penciptaan Seni Program Pascasarjana STSI Surakarta Vol. 1 No. 1 April 2002.

Widiastuti Rahma, "Keindahan Bunyi Dalam Pantun Berolek Godhang Masyarakat Melayu Luhak Rokan Kecamatan Rokan IV Koto Kabupaten Rokan Hulu", Skripsi Universitas Riau, 2009

Zoetmolder, Kamus Jawa Kuna - Indonesia, Jakarta: Gramedia Pustaka Utama, 1995 